\title{
The League of Nations and the Protection of the Inhabitants of Transferred Territories
}

\author{
By Manley O. Hudson, LL.B., S.J.D. \\ Harvard Law School
}

\begin{abstract}
CURRENT discussion of the policy of the United States toward the work of the Paris Conference has centered chiefly on the immediate advantages which may accrue to the American people from the post-war liquidation, and on the commitments which we may undertake for the event of future wars. The confusion which has been engendered in the course of this discussion has tempted us to forget some of the responsibilities which the United States shares with the other principal belligerents, as a result of the rôle we played in achieving the Allied victory. It was not surprising that the zeal for success should have diverted attention from the ends to be served by victory while hostilities were still in progress, but war zeal generally outlives its usefulness and tends to becloud the understanding upon which the political solutions wrought by war depend.
\end{abstract}

Any peace which might have been made in 1919 would certainly have resulted in the creation of the new states of Poland and Czecho-Slovakia, in the transfer of some territory to Italy and Jugo-Slavia and Roumania and Greece, and in the disannexation of some of Germany's possessions over-seas. The very progress of the war, as it had developed during 1917 and 1918, made it inevitable that a new map of Europe should be drawn. Even if the travail of pre-war European politics had not pointed in this direction, the expression which President Wilson gave to the political aims of the Allies made it impossible to continue the status quo ante bellum. His rallying of Allied opinion to the slogans of democracy and self-determination may have been more genuine among dissatisfied peoples in Europe than among his own fellow citizens, but the war meant to many Americans a release of oppressed peoples from the domination of their unwilling masters.

"The principle of justice to all peoples and nationalities, and their right to live on equal terms of liberty and safety with one another whether they be strong or weak," was proclaimed by President Wilson and believed by many millions of men and women, on both sides of the struggle, to run through the whole program of the fourteen points. As such, it was embodied in the compact which the American people made, in continuing as well as in ending the hostilities, with the peoples of Eastern Europe and the inhabitants of German territories outside of Europe. The responsibilities of endeavoring to give them complete protection in the territorial readjustment rested primarily on the peoples who were chiefly instrumental in the defeat of the central powers. A settlement which did not face these responsibilities would not only have failed to safeguard the future peace, but it would also have betrayed the solemn faith which the Allies had pledged.

I propose to discuss some of the measures which the Paris conference designed to discharge this responsibility of the United States and the other principal belligerents, and to suggest that the enforcement of these measures and the realization of their purposes must still find a place in American foreign policy if we are living up to our obligations and if we are to play the 
part which opinion throughout the world has learned to expect of America.

I should feel more comfortable if I might begin by rejecting the expression "backward peoples" which finds a place in the subject of our discussion. Perhaps the phrase is due to the covenant's description of the mandatories as "more advanced peoples" who are to exercise tutelage over the native inhabitants of mandated territories. It may be part of the western world's belief in the idea of progress that we have come to think of the events of the last century, particularly the industrial revolution, as having greatly advanced the peoples who have shared in them most largely. There is a sense in which this advancement is not to be questioned - the volume of the world's wealth has greatly increased with our capacity to develop its natural resources-but the evaluation which the future will put upon our civilization may turn upon criteria in which such factors as the industrial revolution will not play the dominant part. The danger of classifying peoples as "backward" or "advanced" should therefore be avoided, and it is sufficient for our present purposes to say that we find some peoples in a position where they are quite likely to be exploited,economically or culturally, unless special protection is accorded to them. This is certainly true of some of the native tribes in Africa, and it is hardly less true of certain peoples in Eastern Europe and in the Near East.

The Peace Conference had the task of devising measures for the protection of these peoples, and I think the result has been a large contribution to the body of public law which we are gradually building up through the generations. With reference to the peoples of Eastern Europe, these measures were formulated in the special minority treaties concluded with the new states of Poland and Czecho-Slovakia, and with the enlarged states of Jugo-Slavia and Roumania and Greece, and in the similar minority provisions included in the peace treaties with Austria and Hungary and Bulgaria and Turkey. Precedents were many for these attempts to secure the liberties and special interests of peoples inhabiting transferred territories. The nineteenth century had witnessed the growth of a new practice in the transfer of territory. At the very beginning of the century, the treaty by which France ceded the Louisiana territory to the United States had vouchsafed to the inhabitants protection of their liberty, property and religion, and this obligation rested on our federal government as an international undertaking until the states carved out of the Louisiana Purchase had been admitted into the Union. The example was followed in numerous other treaties. By 1878, the practice had lost its novelty, and when the Congress of Berlin set up the new states of Montenegro and Serbia and Roumania, it conditioned their independence on their guaranteeing religious freedom and political equality to the mixed groups who composed their respective populations. These guarantees were framed as international undertakings, and in the Treaty of Berlin they became a part of the organic law of the European state system.

The Paris conference was not blazing a new path, therefore, in adopting the policy of externational guarantees to the peoples of Eastern Europe. But in the contents of the nine treaties for protecting racial, religious and linguistic minorities, it went very much beyond any previous effort. The world had just been through an era of ruthless compulsion, in the course of which the nationalizing process had been carried to great extremes. Eastern 
Europe had been the theatre of many excesses which the cessation of hostilities had by no means ended. While the Paris conference was working, reports of these excesses were rife and were fanning the flames of discontent and disintegration which threatened to envelop the continent. The stories of pogroms against the Jews in Poland, and of language difficulties of the Germans in Czecho-Slovakia, seemed to indicate that efforts were being made in these regions to nationalize whole populations over night. The situation obviously necessitated very strong assurances being given to such peoples as the Germans who felt that their social and political affairs were being handed over to the control of inferior peoples, and the unfortunate history of the guarantees in the Treaty of Berlin strongly reënforced the significance of the current events.

The minority provisions, therefore, envisage a considerable limitation on the action of certain states in dealing with the peoples inhabiting their new territories. They assure to all the inhabitants full and complete protection of life and liberty, without distinction as to birth, nationality, race or religion, as well as the privilege of practising in public and in private any religion which is not inconsistent with public order and public morals. The history of Roumania's discriminations against the Jews by the device of classifying them as aliens although their families had lived in Roumania for generations, made it seem necessary to elaborate provisions assuring to all inhabitants in the transferred territories the citizenship of the state to which they should owe allegiance. The protection of their cultural and religious liberty, without distinctions based on race or language or religion, seemed to call for their being given some share in the control of their local institutions, particularly the schools in which their children are taught.

The efforts of a distinctive group to perpetuate itself will very frequently center on preserving the use of its language in the schools. We all recall the stories of the strikes of the Polish children when they were compelled to say their prayers at school in the German language. It was not enough that the children were taught their parents' tongue. Their instruction at school had to be in the medium of their parents' tongue if group solidarity was to be kept alive. In line with this insistence, the minority treaties require that in districts where a considerable part of the population belongs to a linguistic or religious minority, public schools shall be provided in which the instruction shall be consistent with that minority's religion and in the medium of its language.

Of course, such treaty provisions do not execute themselves. Black ink on white paper can not solve the social problems with which they deal. If proof of this were needed, we have had it in ample measure in the United States in the events of the last few months which have shown how miserably we have failed to realize the substance of the thirteenth amendment to our constitution. The frustration of the attempt of the Congress of Berlin to protect the Jews in Roumania was a warning to the peace conference. The Treaty of Berlin had failed to provide any sanction for its work, so that when in 1902 Secretary John Hay: protested against the Roumanians' reducing the Jews to a "state of wretched misery," his protest was largely ineffective. No machinery was at hand for the externational enforcement of Roumania's undertaking, upon which her very recognition had been conditioned. The Paris conference, therefore, did not content itself with making 
the minority provisions "obligations of international concern." It placed them under the guarantee of the League of Nations. The Council of the League is especially empowered to enforce the provisions, and in case of "any infraction or any danger of infraction," it is to "take such action and give such direction as it may deem proper and effective in the circumstances." An aggrieved minority can not directly appeal to the League, however. It must induce the delegate of some power represented on the Council to present its claim. Such a limitation on a minority's appeal would not have precluded the Roumanian Jews from relief in 1902, and Secretary Hay's protest might then have yielded some results if the concert of Europe had been an effective League of Nations.

These provisions for protecting the minorities in Eastern Europe afford some guide for determining the measures which ought to be included in the mandates for protecting the inhabitants of former German and Turkish territories placed under the mandate system. As to some of the mandated territories, the problem is very dissimilar, but certain of the principles applied in the minority treaties ought to be further entrenched in international law by being included in the mandates. Article XXII of the covenant was drafted before the Paris conference had begun its work on the minority treaties, and its provisions for protecting the native peoples are not so explicit as the conference at a later stage might have made them.

The theory of the so-called A mandates over "certain communities formerly belonging to the Turkish Empire" is that the existence of these communities as independent states is provisionally recognized. It would seem that such mandates should contain guarantees as strong as those given by Poland and Czecho-Slovakia whose independence was recognized definitively. The British draft mandate for Mesopotamia, as submitted to the Council of the League of Nations by Mr. Balfour last December, contains the following provision:

The Mandatory will ensure to all complete freedom of conscience and the free exercise of all forms of worship, subject only to the maintenance of public order and morals. No discrimination of any kind shall be made between the inhabitants of Mesopotamia on the ground of race, religion or language. Instruction in and through the medium of the native languages of Mesopotamia shall be promoted by the Mandatory.

The right of each community to maintain its own schools for the education of its own members in its own language (while conforming to such educational requirements of a general nature as the Administration may impose) shall not be denied or impaired.

Similarly, the draft mandate for Palestine which was submitted to the Council at the same time, contains a provision as follows:

The Mandatory will see that complete freedom of conscience and the free exercise of all forms of worship, subject only to the maintenance of public order and morals, is ensured to all. No discrimination of any kind shall be made between the inhabitants of Palestine on the ground of race, religion or language. No person shall be excluded from Palestine on the sole ground of his religious belief.

The right of each community to maintain its own schools for the education of its own members in its own language (while conforming to such educational requirements of a general nature as the Administration may impose) shall not be denied or impaired.

The French draft mandate for Syria and Lebanon contains substantially similiar provisions. While these provisions are not so complete as those of 
the minority treaties, they seem fairly adequate for meeting the needs of the different racial, religious and linguistic groups in Mesopotamia and Palestine, and they are welcome applications of the general principles on which the minority treaties are based.

The contents of the so-called B mandates for Central African territories and the so-called $\mathrm{C}$ mandates for southwest Africa and the southern Pacific Islands were more definitely prescribed in Article XXII of the covenant. The mandatory is required to administer the territory "under conditions which will guarantee freedom of conscience and religion, . . . the prohibition of abuses such as the slave trade, the arms traffic, and the liquor traffic, and the prevention . . . of military training of the natives for other than police purposes and the defense of the territory." It is most important that the strict fulfillment of this provision shall be insisted upon. Indeed, its strict fulfillment is essential to the success of the mandate idea.

The control of the arms traffic has been recently regulated by the Arms Traffic Convention, signed at Paris in September, 1919, and the extension of this convention to all the African territories and the Pacific Islands held under mandate would seem a necessary step in executing the provisions of the covenant. This extension has been provided for in the British mandates approved by the Council of the League on December 17, 1920, covering Southwest Africa and the Pacific Islands, though it seems to have been omitted from the British and Belgian draft mandates for East Africa and the British and French draft mandates for Togoland and the Cameroons.

It is even more important that the natives in the African territories and Pacific Islands should, under no circumstances, be armed "for other than police purposes and the defense of the territory." The difficulties which have arisen in applying this part of Article XXII seem to throw doubt on the good faith with which some of the powers are carrying out the mandate idea. And unless there is a clear and unequivocal statement of this guarantee in each of the B mandates, as they are to be finally agreed upon, the "sacred trust of civilization" which is proclaimed by the covenant will offer the cynics an awaited opportunity. The French draft mandates for Togoland and the Cameroons as submitted to the Council of the League last December contain a provision that in the event of a general war the native troops may be used to protect the mandatory's territory outside the mandated region, and it seems difficult to reconcile such a provision with the requirements of Article XXII.

The liquor traffic is interdicted to the whole continent of Africa by the Convention on Spirits in Africa, signed at St. Germain in September, 1919, and the prohibition of the slave traffic in certain parts of Africa has been enacted in the convention revising the Brussels and Berlin Acts, signed at the same time. But these two latter conventions have not yet been ratified and their provisions are not mentioned in the mandates already approved. The drafts of the $\mathbf{B}$ mandates contain very satisfactory provisions concerning the slave trade and the suppression of existing slavery, and they seem to provide sufficiently for the control of the liquor traffic.

The mandates already approved by the Council of the League seem to me to give great promise for the success of the idea, so far as it envisages the protection of the interests of indigenous populations. Supervision of their execution and the work of the permanent mandate commission must now be 
begun as soon as the remaining mandates have been approved. It seems not too sanguine to hope, therefore, that with the completed launching of the system we shall have passed beyond the possibility of repeating such scandals as those in the Belgian Congo, which so disturbed American opinion a few years ago, or such an atrocity as the Germans' massacre of the Herreros.

The success of the mandate system is still depending on many factors. Chief among them, it seems to me, is the will that it shall succeed. The formation of this will and its effective assertion, require in each country a body on informed and intelligent opinion which is ready and active as each issue arises. Such an opinion is much needed in the United States today. We have professed at various times an interest in seeing that justice is done to the minority peoples of Eastern Europe, and an interest in the well-being of the natives of Africa. It is not enough that this interest should find expression when a particularly flagrant outrage such as that in the Congo has excited popular passion. The constructive effort which conditions the success of the minority treaties and the mandate system requires more than a week of headlines for its building.

If such interest exists in America today, it seems to me that it should insist that the protection of minorities in the new states of Europe and of natives in the mandated territories should find a place in the newly formulated foreign policy of the United States. Our government has taken the position that the United States is "directly interested in the terms of the mandates," and both Secretaries Colby and Hughes have given forceful ex- pression to this interest in connection with their efforts to secure equality of commercial treatment for American citizens in mandated territories. It would be a flouting of the whole mandate idea if a mandatory should use its position to exploit for itself or its friends the natural resources of the mandated territory, and unless equal access to such resources is provided for all foreigners, little progress will have been made in removing the chief source of international friction before the war.

But the government of the United States should not confine its interest in the terms of the mandates to securing business opportunities for American citizens. We can not discharge the responsibilities which came to us from the war by basing our foreign policy merely on a dollar diplomacy. To the minorities in Eastern Europe the American people have an obligation which ought to be discharged by some kind of ratification of the treaties with Poland and Czecho-Slovakia and Jugo-Slavia and Roumania and Greece. If such ratification must await our final action on the peace treaties, it ought to be none the less assured when that time comes. To the natives in former German territories in Africa and the Pacific, we have an obligation which ought to be met by our participation in framing the mandates and in supervising their execution. The simple method of handling both of these responsibilities would seem to be to take our place in the councils of the League of Nations. But short of that, we should insist that a way be found for us to play our part in making good on the Allies' wartime professions, and to justify the confidence and hope with which so many peoples still look to us for protection and sympathy. 